\title{
COMMENTS
}

\section{The Resolution Trust Corporation's Override Regulation: Freedom for Intrastate Branch Banking}

\author{
Jeryl Bowers $\dagger$
}

In 1989, one out of every eight savings and loan associations ${ }^{1}$ was broke. ${ }^{2}$ The industry had been losing $\$ 20$ million a day. ${ }^{3}$ The situation led one senator to remark that the cost of resolving the crisis will "be bigger than the combined cost of the assistance provided to Lockheed, Chrysler, Penn Central, New York City, and for good measure, you can throw in the Marshall Plan." 4 In fact, it may cost taxpayers $\$ 157$ billion over the next thirty-three years to resolve the savings and loan mess. ${ }^{5}$

To help curtail the rising costs of this crisis, in 1989 Congress enacted the Financial Institutions Reform, Recovery and Enforcement Act ("FIRREA"). ${ }^{6}$ FIRREA created the Resolution Trust

† B.A., Howard University, 1990; J.D. Candidate 1993, The University of Chicago.

2 Throughout this Comment, the terms savings and loan association, savings and loan, savings association, and thrift are used as synonyms.

${ }^{2}$ David Elbert and Harriet Johnson Brakey, $S \& L$ success stories; They made sound rules and stuck by them; Slow growth was the key to survival, USA Today 1B (Feb 15, 1989).

3135 Cong Rec E2957 (Sep 6, 1989) (McMillen).

135 Cong Rec S10403 (Aug 15, 1989) (Wirth).

B Id.

- 12 USC \$§ 1422 et seq (Supp II 1990). For a detailed description of FIRREA, see Vicki O. Tucker, Patti G. Meire, and Phyllis M. Rubinstein, The RTC: A Practical Guide to the Receivership/Conservatorship Process and the Resolution of Failed Thrifts, 25 U Richmond L Rev 1 (1990). See also Paul T. Clark, Bryan M. Murtagh, and Camile Corcoran, Regulation of Savings Associations Under the Financial Institutions Reform, Recovery, and Enforcement Act of 1989, 45 Bus Law 1013 (May 1990). 
Corporation ("RTC") to manage the sale of insolvent thrifts" to banks and other federally-insured depository institutions. ${ }^{8}$ Proceeds from the sales supplement the government's reimbursement of federally-insured depositors. As part of its statutory mission, the RTC must maximize the net present value and minimize the amount of loss realized from the sale of failed thrifts. ${ }^{9}$

Although the RTC may facilitate the sale and acquisition of failed thrifts to depository institutions in order to raise funds, these transactions will be governed by the restrictions of state laws. However, when severe financial conditions threaten a significant number of savings associations, FIRREA empowers the RTC to preempt state laws that inhibit emergency acquisitions of failed thrifts. Pursuant to this emergency acquisition authority, the RTC adopted the "Override Regulation," which authorizes banks to operate branches of failed thrifts as bank branches in contravention of state branch banking laws. ${ }^{10}$ The Override Regulation was designed to encourage banks to include thrift branches in their purchases of failed thrifts. To date, the RTC has utilized the emergency acquisition provision and overridden state branch banking laws thirty-seven times. ${ }^{11}$

Several states, concerned with enforcing their branch banking laws, and local banking associations, concerned with the competitive impact of allowing large national banks to branch, have challenged the RTC's Override Regulation, arguing that branch banking laws are beyond the RTC's statutory preemption power. ${ }^{12}$ Although both circuits that have considered the issue have sided

${ }^{7}$ A thrift is insolvent when its debts are greater than the aggregate of the thrift's property at a fair valuation. See American National Bank v Bone, 333 F2d 984, 987 (8th Cir 1964).

Tucker, Meire, and Rubinstein, $25 \mathrm{U}$ Richmond L Rev at 38 (cited in note 6).

- 12 USC $\S 1441 \mathrm{a}(\mathrm{b})(3)(\mathrm{C})$ (i)-(iv).

10 12 CFR § 1611.1 (1991). State branch banking laws may either prohibit banks from operating any branches at all or restrict the operation of bank branches to a small geographic area close to the main office. Such laws typically protect local banks from competition from large national banks.

${ }^{11}$ Conversation with a representative from the RTC's Corporate Communication Department (Jan 8, 1992) (internal memos for the thirty-seven state law overrides are on file with U Chi L Rev).

${ }_{12}$ See Arkansas State Bank Commissioner v RTC, 911 F2d 161 (8th Cir 1990); Independent Community Bankers of New Mexico v RTC, No Civ 90-0532-SC, slip op, 1990 US Dist LEXIS 18584 (D NM), aff'd, 926 F2d 936 (10th Cir 1991); Colorado State Banking Board v RTC, 926 F2d 931 (10th Cir 1991). For a detailed description of the historical development of this dispute in the case law, see David Whitney Adams, Is the Power of the RTC Unlimited?-Federal Preemption of State Banking Law, 18 Fla St U L Rev 995 (1991). 
with the RTC, the issue has deeply divided these courts. ${ }^{13}$ The majorities have maintained that FIRREA grants broad preemption authority to the RTC and thus empowers it to override state branch banking laws. ${ }^{14}$ The dissents have argued that the preemption of branch banking laws exceeds the RTC's statutory power and violates federal law requiring national banks to submit to state branch banking laws. ${ }^{16}$

This Comment argues that the Override Regulation is a valid exercise of the RTC's statutory authority. Section I provides an overview of the regulatory regimes of the banking and thrift industries. Section II examines FIRREA and the RTC's role in resolving failed thrifts. Section III analyzes the statutory language and legislative history of FIRREA. ${ }^{16}$ Section IV analyzes the Override Regulation under the Cheuron standard of review and weighs the competing policy concerns for and against preserving branch banking laws. This Comment concludes that the RTC's Override Regulation is supported on all fronts; it is authorized by the language of FIRREA, consistent with FIRREA's legislative history, a permissible construction of the statute under Chevron, and a reasonable accommodation between the nation's vital interest in resolving failed thrifts and the nation's lesser interest in preserving some states' branch banking laws.

${ }^{13}$ See Arkansas State Bank Commissioner, 911 F2d 161; Colorado State Banking Board, 926 F2d 931. Each case contains a strong dissent. See Arkansas State Bank Commissioner, 911 F2d at 175 (Heaney dissenting); Colorado State Banking Board, 926 F2d at 948 (Ebel dissenting). At the district court level, only one judge sided with the RTC, while two others held the Override Regulation an invalid exercise of the RTC's regulatory power. Compare Independent Community Bankers of New Mexico, No Civ 90-0532-SC, slip op, 1990 US Dist LEXIS 18584 (finding the regulation valid) with Arkansas State Bank Commissioner v RTC, 745 F Supp 550 (E D Ark), vacated, 911 F2d 161 (8th Cir 1990); Colorado State Banking Board v RTC, No 90-Z-190 (D Colo 1990), rev'd, 926 F2d 931 (10th Cir 1991) (finding the regulation invalid). Of the nine federal judges to have addressed the issue, five have sided with the RTC and four with the states.

"Arkansas State Bank Commissioner, 911 F2d at 174; Colorado State Banking Board, 926 F2d at 945-47.

${ }_{13}$ Arkansas State Bank Commissioner, 911 F2d at 170 (Heaney dissenting); Colorado State Banking Board, 926 F2d at 950 (Ebel dissenting).

${ }^{16}$ There are no constitutional federalism issues because Congress has the ability to preempt state law under the Commerce and Supremacy Clauses of the U.S. Constitution. US Const, Art I, § 8, cl 3; Art VI. 


\section{The Dual Regulation of the Banking and Thrift INDUSTRIES}

A. The Dual Banking System

Both the federal and state governments regulate the banking industry. ${ }^{17} \mathrm{~A}$ bank must obtain a charter to operate, but can choose to obtain one from either the federal government's Comptroller of the Currency or a state government's banking authority. Once chartered, the federal or state authority that issued the charter will continue to regulate the bank. Nonetheless, a bank may still convert its charter to the alternative regulatory system if it obtains the consent of that agency. ${ }^{18}$ Today, in every state except Pennsylvania, more banks are chartered by state regulators than by national regulators. ${ }^{19}$

1. Purpose of the regulatory system.

The banking industry is regulated for two reasons. First, consumer deposit protection is essential because bankers are custodians of public funds. ${ }^{20}$ Second, a highly competitive banking industry might cause a significant number of bank failures. These failures would in turn destroy consumer and commercial borrowing relationships and erode public confidence in the banking system. ${ }^{21}$ The regulatory system serves to prevent these consequences by regulating the number and location of banks in any given area.

2. Origin of the dual banking system.

Until 1863 banks were chartered, and therefore regulated, almost exclusively by the states. ${ }^{22}$ In order to finance the Civil War, Congress enacted the National Bank Act, which established a national chartering authority for banks. ${ }^{23}$ The Act established the Comptroller of the Currency and gave it authority to charter new national banks. ${ }^{24}$ Congress wanted to replace the state banking sys-

17 Douglas H. Ginsburg, Interstate Banking, 9 Hofstra L Rev 1133, 1139 (1981).

${ }^{18}$ Kenneth E. Scott, The Dual Banking System: A Model of Competition in Regulation, 30 Stan L Rev 1, 8-12 (1977).

19 Id.

${ }^{20}$ Ginsburg, 9 Hofstra L Rev at 1142 (cited in note 17).

21 Id.

22 Id at 1139.

${ }^{23}$ Comment, Circumventing the McFadden Act: The Comptroller of the Currency's Efforts to Broaden the Branching Capabilities of National Banks, $72 \mathrm{Ky} \mathrm{L} \mathrm{J} \mathrm{707,} \mathrm{710}$ (1983-84).

24 Id at 711 . 
tem with a national system to provide a ready market for the Civil War bonds the federal government was floating. ${ }^{25}$ To further this ambition, national charters were given only to banks that purchased a significant number of U.S. bonds, while a two percent tax penalty was imposed on state banks that refused to convert to the national system. ${ }^{26}$ Perhaps the Act's most powerful inducement to federal chartering, however, was its designation of national banks as the official depositories of U.S. funds.

The state banking system survived, however, in part because the increasingly popular checking accounts were exempt from the two percent tax penalty imposed on state bank notes. In addition, state regulations were often less restrictive than the federal counterparts. ${ }^{27}$

3. Competition within the dual banking system.

Banks generally prefer a dual banking system to a single system because it imposes a competitive check on bank regulators. ${ }^{28}$ When chartering new banks, both the national and state chartering authorities must consider the needs of the community and whether existing banks can withstand extra competition. However, the implementation of these standards may vary between the systems. The dual banking structure encourages bank regulators to issue more liberal regulations, because if one system becomes too restrictive, banks may switch to the other. ${ }^{29}$ However, the incentive for both the Comptroller and state regulators to provide liberal regulations is balanced by their concern for avoiding bank failures. ${ }^{30}$

\section{Restrictions on branch banking.}

The National Bank Act did not expressly give national banks the power to branch. ${ }^{31}$ Consequently, the Comptroller of the Currency and the Supreme Court concluded that national banks were prohibited from branching. ${ }^{32}$ This ruling placed the national banking system at a competitive disadvantage when some states broad-

26 Id; Ginsburg, 9 Hofstra L Rev at 1140 (cited in note 17).

26 Ginsburg, 9 Hofstra L Rev at 1140 (cited in note 17).

${ }^{27}$ Id at 1141 .

28 Id.

29 The undesirable regulatory system will also lose the additional revenue generated from new bank charters.

30 Ginsburg, 9 Hofstra L Rev at 1145 (cited in note 17).

${ }^{31}$ Comment, $72 \mathrm{Ky} \mathrm{L} \mathrm{J}$ at 712 (cited in note 23).

${ }^{32}$ See First National Bank v Missouri, 263 US 640, 658-60 (1924). 
ened the branching authority for their state-chartered banks. The new state policy resulted in a dramatic shift from national to state charters because state-chartered banks could gain a competitive advantage over national banks by following their customers to the suburbs, a considerable convenience for the banking public. ${ }^{33}$ To preserve the competitiveness of national banks, in 1927 Congress passed the McFadden Act. ${ }^{34}$ This legislation gave national banks branching authority equivalent to that of state banks by making the branching provisions of state law applicable to national banks. ${ }^{35}$

The Great Depression led to a further liberalization of branch banking restrictions. The failure of many unit banks ${ }^{36}$ during the Great Depression bolstered the belief that branch banking would provide more stability to the banking system. ${ }^{37}$ Consequently, the Comptroller of the Currency, among others, argued that national banks should be allowed to branch regardless of state law. To avoid repeal of the McFadden Act, some states relaxed their branching statutes to allow county- or state-wide branching. ${ }^{38}$ This strategy succeeded; Congress made no substantial revision. Thus, the McFadden Act remains the primary branching authority for national banks.

\section{B. The Savings and Loan Industry}

Like banks, the savings and loan industry is governed by a dual state and federal regulatory system. Banks and savings associations both take deposits from their customers. Savings associations, however, have tighter restrictions on their investment

${ }^{33}$ Comment, $72 \mathrm{Ky} \mathrm{L} \mathrm{J} \mathrm{at} \mathrm{712-13} \mathrm{(cited} \mathrm{in} \mathrm{note} \mathrm{23);} \mathrm{Ginsburg,} 9$ Hofstra L Rev at 1152 (cited in note 17 ).

${ }^{34}$ Ch 191, 44 Stat 1224 (1927), current version codified at 12 USC $\S 36$ (1988). The relevant text of the Act reads:

A national banking association may ... establish and operate new branches ... at any point within the State in which said association is situated, if such establishment and operation are at the time authorized to State banks by the statute law of the State in question ... and subject to the restrictions as to location imposed by the law of the State on state banks.

12 USC $\S 36(c)$ (1988).

${ }^{36}$ Comment, $72 \mathrm{Ky} \mathrm{L} \mathrm{J}$ at 713 (cited in note 23 ).

${ }^{36}$ Unit banks are banks that are limited to a single office.

${ }^{37}$ Comment, $72 \mathrm{Ky} \mathrm{L} \mathrm{J} \mathrm{at} 713$ (cited in note 23). First National Bank $v$ Walker Bank, 385 US 252, 259 (1966).

38 Still, as of May 1990, only thirty-five states allow full intrastate branch banking. See Arthur E. Wilmarth, The Expansion of State Bank Powers, the Federal Response, and the Case for Preserving the Dual Banking System, 58 Fordham L Rev 1133 (1990). 
activities than do banks. ${ }^{39}$ Generally, savings associations invest customer deposits in residential housing loans. ${ }^{40}$

The Home Owner's Loan Act ${ }^{41}$ created and authorized the Federal Home Loan Bank Board ("FHLBB") to charter and regulate federal savings and loan associations. The National Housing Act ${ }^{42}$ created the Federal Savings and Loan Insurance Corporation ("FSLIC") to insure the deposits of both state and federal savings associations. Under the National Housing Act, the FHLBB was authorized to regulate all FSLIC-insured state and federal savings associations. ${ }^{43}$

There are few statutory limitations on intrastate branching by federal thrifts. ${ }^{44}$ In fact, since 1980, the FHLBB has allowed FSLIC-insured savings associations to pursue full intrastate branching. ${ }^{45}$ To achieve competitive equality with national regulators, state regulators had to liberalize their branching laws. Thus, unlike the policy that governs banks, the federal government and most states have allowed thrifts to branch statewide. ${ }^{46}$

\section{FIRREA And The RTC's Role in Resolving Thrifts}

A. The Thrift Crisis

Between 1980 and 1988, over five hundred savings associations failed. ${ }^{47}$ As a result, the FSLIC became insolvent from reimbursing savings and loan depositors for their losses. ${ }^{48}$ In fact, the severity of the crisis was such that on December 31, 1986, the FSLIC had a negative net worth of approximately $\$ 6.3$ billion. One year later,

\footnotetext{
30 Problems of the Federal Savings and Loan Insurance Corporation, Part III, 101st Cong, 1st Sess, 113 (1989) ("FSLIC Report").

10 Id.

148 Stat 128 (1933), codified at 12 USC $\S 1461$ (1989).

${ }^{42}$ Pub L No 73-479, 48 Stat 1246, 1255, 1256 (1934), codified at 12 USC $\$ 1715$ (1989).

43 12 USC § 1715 (1989) (repealed by FIRREA § 407).

4 Financial Market Deregulation, Am Bank 5 (Mar 13, 1984).

4s An Examination of Deregulation, Am Bank 8 (Jun 22, 1984).

16 The weaker resistance to branching in the thrift industry is probably due to the smaller number and relative political strength of savings associations. As of 1988, there were only 3,092 FSLIC-insured thrifts. A Project for Bush: Shoring Up Deposit Insurance, Am Bank 16 (Nov 30, 1988). Compare this modest figure with the 15,000 commercial banks chartered in 1985. Stephen M. Shapiro, Interstate Banking in the 1980's: Supreme Court Docket and Congressional Agenda, 499 PLI/Corp 291 (Oct 1, 1985). The political muster of the state savings associations was not sufficient to force Congress to protect their interests by limiting the branching activities (and thus competition) of federal thrifts within their states.

47 Financial Institutions Reform, Recovery and Enforcement Act of 1989, S Rep No 101-19, 101st Cong, 1st Sess 2 (1989).

4 Id.
} 
this deficit doubled to $\$ 13.7$ billion. ${ }^{49}$ By the end of 1988 , the FSLIC's negative net worth had plummetted to approximately $\$ 50$ billion. ${ }^{50}$

Meanwhile, the FHLBB, which was responsible for administering the FSLIC, lacked the funds to close hundreds of other insolvent and thinly capitalized savings associations because it could not afford to compensate the insured depositors. ${ }^{51}$ These ailing savings associations continued to operate and incurred losses estimated at approximately $\$ 20$ million per day. ${ }^{52}$ Ironically, these losses continued to increase the gargantuan obligations of the FSLIC. . $33^{3}$

\section{B. FIRREA's Response to the Thrift Crisis}

In February 1989, Congress and President Bush commenced work on FIRREA to save the failing thrift industry and reduce the government's financial obligation to insured depositors. Congress rushed FIRREA through in six months amidst intense debate. It was signed into law in August 1989. Given the swiftness with which it was conceived and enacted, FIRREA contains many ambiguities.

FIRREA was a drastic measure to control the rising costs of the savings and loan crisis. It eliminated the FSLIC and transferred its insurance obligations to the Federal Deposit Insurance Corporation ("FDIC"). ${ }^{54}$ The Office of Thrift Supervision ("OTS") replaced the FHLBB, and now regulates all federal and state savings associations. ${ }^{55}$ The OTS also appoints conservators and receiv$\mathrm{ers}^{86}$ for failed savings associations. FIRREA created the Resolution Trust Corporation ("RTC") ${ }^{57}$ to manage the sale of savings associations. However, the RTC is an emergency regulatory au-

\footnotetext{
49 Condition of the Federal Deposit Insurance Funds before the House of Representatives Committee on Banking Finance, Finance, and Urban Affairs, 100th Cong, 2d Sess 185 (Statement of M. Danny Wall, Chairman, FHLBB).

${ }^{\text {so }}$ HR Rep No 101-54, 101st Cong, 1st Sess 304, reprinted in 1989 USCCAN 86, 100.

51 United States General Accounting Office, Forbearance for Troubled Institutions 1982-1986, 3, 11, (May 1987). On December 31, 1988, 754 of the 2,949 FSLIC-insured institutions were either insolvent or on the brink of insolvency. HR Rep No 54 at 101 (cited in note 50).

${ }^{82} 135$ Cong Rec E2957 (Sep 6, 1989) (Representative McMillen).

${ }^{53}$ Id.

s4 12 USC $\S 1811,1814(a)(2), 1815$ (1990).

${ }^{\text {ss }} 12$ USC $\$ 1462 \mathrm{a}(\mathrm{a})$.

${ }^{86} \mathrm{~A}$ conservator operates or disposes of a savings association as a going concern. A receiver liquidates the assets and terminates the affairs of a failed savings association. See Tucker, Meire, and Rubinstein, 25 U Richmond L Rev at $8 \mathrm{n} 34$ (cited in note 6).

${ }^{37}$ The RTC's duties are actually performed by the FDIC, whose board of directors serves as the board of directors of the RTC.
} 
thority and is therefore temporary; it will terminate on August 9, $1994 .{ }^{58}$

1. RTC's ability to resolve thrifts.

Once the RTC is appointed to manage an insolvent or ailing thrift, it acquires all of the thrift's rights, titles, privileges, and powers and may control the thrift's assets and operations. The RTC is also empowered, among other things, to: (1) merge the association with another federally-insured depository institution; (2) transfer any asset or liability of the association to another depository institution; $;^{59}$ (3) obtain a temporary stay of any legal proceeding against the association; and (4) repudiate any contract or lease to which the association is a party. ${ }^{60}$

2. How the RTC sells a thrift: the bidders conference.

To sell a thrift, the RTC invites interested banks and other federally-insured depository institutions to a bidders conference and gives them detailed financial information concerning the failing thrift. ${ }^{61}$ In order to expedite the sale, the RTC gives little time for potential purchasers to inspect the physical premises of the association being marketed. ${ }^{62}$ The purchasers must base their bids almost exclusively on the troubled thrift's financial information. Likewise, all conditions to the bidder's proposal must be included in the original bid, for the RTC will rarely negotiate the terms of the transaction. ${ }^{63}$

When marketing a failed thrift, the RTC seeks a purchaser who will acquire a substantial portion of the failed thrift's assets and liabilities. ${ }^{64}$ Because allocating the assets and liabilities among the branches of a thrift is a difficult and expensive process, the RTC prefers not to sell the branches of failed thrifts separately. ${ }^{65}$

s8 12 USC \& $1441 \mathrm{a}(0)$.

Bo With the consent of the appropriate regulatory agency.

so 12 USC \& $1821(\mathrm{~d})(2)(\mathrm{I})$.

o1 Tucker, Meire, and Rubinstein, 25 U Richmond L Rev at 39 (cited in note 6).

${ }^{62}$ Id at 40.

ss Id.

of A Buyer's Guide: How to Purchase a Savings Association from the RTC, Fed Bank L Rptr (CCH) I 70,503 at 46,519 (Mar 2, 1990).

es 'Tucker, Meire, and Rubinstein, $25 \mathrm{U}$ Richmond L Rev at 39 (cited in note 6). 


\section{The RTC's Override Regulation}

FIRREA authorizes the RTC to override some state laws whenever financial conditions threaten a significant number of savings associations. ${ }^{66}$ This gives the RTC power to facilitate emergency acquisition of failed thrifts to prevent severe financial conditions from further deteriorating.

On June 1, 1990, the RTC adopted the "Override Regulation," which permits insured banks to acquire and operate branches of failed thrifts as bank branches. ${ }^{67}$ Under this regulation, banks can retain and operate these branches regardless of state banking laws. ${ }^{68}$ The RTC adopted the regulation because some states' limitations on branch banking can hinder the RTC's ability to sell troubled thrift branches in emergency situations. ${ }^{69}$ The RTC reasoned that

[b]ecause states that limit bank branching generally do not have comparable laws restricting branching by thrifts, the ability to acquire existing thrift branches can provide a means of branching for which banks would often be willing to pay a substantial premium, provided they are permitted to retain and operate the branches as branches of the bank. Absent this opportunity, banks and bank holding companies are unlikely to bid for troubled thrifts or will bid substantially less because of the cost of chartering and operating the branches as separate banks. ${ }^{70}$

The Override Regulation has been extremely effective in placing a premium on the value of certain failed savings and loan associations. In one instance, a bank was willing to pay a $\$ 1.5$ million premium for the ability to buy a thrift's branches and operate them as bank branches. ${ }^{71}$ Another bank, when faced with the alter-

${ }^{66} 12$ USC \& 1823(k)(1). Although the "severe financial conditions" that will prompt emergency acquisitions are not specifically defined, the provision most likely applies to local situations involving the demise of either large thrifts or of several small thrifts which owe obligations to a substantial number of depositors. Failures such as these could cause a disastrous lack of public confidence in the thrift industry and spark runs on the remaining healthy thrifts. The chain reaction could spark a national run on thrifts if the general public completely loses confidence in the thrift industry. The emergency acquisition provision allows the RTC to quickly sell the thrifts so that the depositors can be reimbursed before they begin to panic.

67 55 Fed Reg 22323 (1990).

68 Id.

69 Id.

20 Id at 22324.

71 See Arkansas State Bank Commissioner, 911 F2d at 163. 
native prospect of individually chartering and capitalizing each thrift branch as a separate bank, reduced its bid by $\$ 600,000 .{ }^{72}$

D. State Response to the Override Regulation

Several states with branch banking restrictions have challenged the RTC's Override Regulation. They argue that preemption of state branch banking laws is beyond the RTC's statutory authority. ${ }^{73}$ They contend that the text of FIRREA does not give the RTC sufficient authority to override branch banking laws, ${ }^{74}$ and that the legislative history of FIRREA conflicts with the RTC's claimed ability to override branch banking laws. ${ }^{75}$ They also argue that the Override Regulation improperly conflicts with the McFadden Act, which gives states the right to determine the branching activity of banks within their borders. ${ }^{76}$ Although two circuit courts have determined that the Override Regulation is valid, they have done so in deeply divided decisions. ${ }^{77}$

\section{Analysis of the OverRIDe Regulation}

No one disputes the RTC's authority to issue regulations to carry out its statutory purpose. ${ }^{78}$ The controversial question is whether FIRREA permits the RTC to override state branch banking restrictions during emergency acquisitions.

The RTC justifies its Override Regulation on three grounds: first, that $\S 1823(\mathrm{k})(1)$ of FIRREA expressly gives the RTC authority to override state law during emergency acquisitions; ${ }^{79}$ second, that the RTC has the authority under $\S 1441$ a of FIRREA to promulgate any regulation it deems necessary to maximize value and minimize loss in sales of thrifts; ${ }^{80}$ and, third, that the branching

72 See Colorado State Banking Board, 926 F2d at 935-36.

${ }^{73}$ Arkansas State Bank Commissioner, 911 F2d at 170-71; Independent Community Bankers of New Mexico, 926 F2d at 945. For a detailed description of the historical development of this dispute in the case law, see Adams, 18 Fla St U L Rev 995 (cited in note 12).

" Arkansas State Bank Commissioner, 911 F2d at 170; Colorado State Banking Board, 926 F2d at 941-42.

${ }^{23}$ Arkansas State Bank Commissioner, 911 F2d at 174; Colorado State Banking Board, 926 F2d at 940.

${ }^{76}$ Arkansas State Bank Commissioner, 911 F2d at 173-74; Colorado State Banking Board, 926 F2d at 945 . The relevant portion of the McFadden Act is contained in note 34 .

77 See note 13 .

${ }^{78} 12$ USC § $1823(\mathrm{k})(1)$.

70 Arkansas State Bank Commissioner, 911 F2d at 168; Colorado State Banking Board, 926 F2d at 934.

${ }^{80}$ Arkansas State Bank Commissioner, 911 F2d at 168; Colorado State Banking Board, 926 F2d at 934 . 
provisions of $\S 1823(\mathrm{k})(4)$ authorize banks to retain savings associations as bank branches in contravention of state law. ${ }^{\mathbf{2 1}}$ This section analyzes these contentions and concludes that, although $\S 1823(\mathrm{k})(4)$ is ambiguous, the plain meaning and legislative history of $\S 1823(\mathrm{k})(1)$ and the broad mandate of $\S 1441$ a support the conclusion that FIRREA authorizes the RTC to override state branch banking laws.

A. Textual Analysis

1. Section $1823(k)(1)$ : authority to override state laws.

FIRREA's general section regarding emergency acquisitions provides in pertinent part:

(i) Transactions described

Notwithstanding any provisions of State law, upon determining that severe financial conditions threaten the stability of a significant number of savings associations, or of savings associations possessing significant financial resources, the Corporation [RTC], in its discretion and if it determines such authorization would lessen the risk to the Corporation, may authorize-

(I) a savings association ... to merge or consolidate with, or to transfer its assets and liabilities to, any other savings association or any insured bank....

(ii) Terms of transactions

Mergers, consolidations, transfers, and acquisitions under this subsection shall be on such terms as the Corporation shall provide...

(vi)Continued applicability of certain state restrictions

Nothing in this subsection overrides or supersedes State laws restricting or limiting the activities of a savings association on behalf of another entity. ${ }^{82}$

It is apparent that $\S 1823(\mathrm{k})(1)$ authorizes the RTC to override state branch banking laws. ${ }^{83}$ The broad authority specifically granted by the Act-"Notwithstanding any provisions of state law

81 Arkansas State Bank Commissioner, 911 F2d at 168.

82 12 USC $\$ 1823(\mathrm{k})(1)(\mathrm{A})$ (emphasis added).

83 Both appellate courts to have considered the issue have agreed. Colorado State Banking Board, 926 F2d at 937-40; Arkansas State Bank Commissioner, 911 F2d at 170. 
[the RTC] . . may authorize a savings association ... to merge or consolidate or transfer its assets and liabilities to any other savings association or any insured bank"-makes apparent Congress's intention to grant the RTC broad discretion to make rules and regulations to facilitate emergency acquisitions by insured banks. The broad authority to override state law is further emphasized by $\S 1823(\mathrm{k})(\mathrm{ii})$ 's provision that "mergers, consolidations, transfers, and acquisitions under this subsection shall be on such terms as the Corporation shall provide." 84

The sole explicit restriction on the RTC's ability to override state law states that "nothing in this subsection overrides or supersedes state laws restricting or limiting the activities of a savings association on behalf of another entity." 85 This clause restricts the activities of a savings association that is operating as an agent for another business entity. However, it does not apply to branch banking restrictions because it does not refer to the activities of savings associations that have been acquired and converted to banks. These entities, of course, are no longer savings associations, but instead are absorbed into and actually become part of the acquiring bank. Consequently, any previous restrictions on their activities as savings associations no longer apply once they become banks, because there are no longer two distinct entities involved. ${ }^{86}$

Moreover, because the text includes this express restriction, it illustrates that Congress must have contemplated the potential ramifications of the RTC's broad authority to override state law. Despite its awareness of this potential, Congress decided that only state laws that restrict the activities of savings associations on behalf of other entities were significant enough to preserve. The negative implication of this provision is that the RTC has wide discretion to override state laws in any other contexts. Nothing in the statute implies that state branching laws are sacrosanct.

2. Section 1441a: RTC's statutory duty to maximize profit and minimize loss.

The Override Regulation is not only consistent with the language of $\S 1823(\mathrm{k})(1)$, but is essential for the RTC to fulfill its stat-

84 12 USC $\$ 1823(\mathrm{k})(1)(\mathrm{A})(\mathrm{ii})$ (emphasis added).

85 12 USC $\$ 1823(k)(1)(A)(v i)$.

so In fact, this provision was intended to be very narrow in application. It was intended to prevent such activities as savings associations "marketing insurance products on behalf of an insurance company." See Section by Section Analysis of S775, in 135 Cong Rec S6912 (Jun 12, 1989). See text accompanying note 105. 
utory duty under $\S 1441$. FIRREA grants the RTC broad authority to issue such regulations as it considers "necessary or appropriate" to manage the sale of failed savings associations. ${ }^{87}$ That authority is granted as a means of implementing the RTC's duty to "maximize the net present value return from the asset sale of savings associations" and "minimize the amount of any loss realized in the resolution of cases." 88 The RTC's Override Regulation and its interpretation of $\S 1823(\mathrm{k})$ is consistent with the agency's duty under $\S 1441$ a to maximize profit and minimize loss. By allowing banks to operate savings and loan associations as bank branches, the RTC can maximize the salvage value of a failed thrift.

The events that gave rise to Independent Community Bank$e r s^{89}$ illustrate this point. The RTC invited 350 interested investor groups, thrifts, thrift holding companies, banks, and bank holding companies to attend a bidders conference for the acquisition of a failed savings and loan association. ${ }^{30}$ Only two banks submitted bids for the failed thrift and each expressly conditioned its bid on the RTC's override of New Mexico branch banking restrictions. ${ }^{91}$ One bank that offered to purchase the assets of the thrift and its four offices did not submit an alternative bid for the thrift if the RTC did not override New Mexico's state branch banking restrictions. Presumably, if the RTC could not override state branch banking provisions, there would have been only one bid for the thrift.

The background to Colorado State Banking Board v RTC ${ }^{92}$ and Arkansas State Bank Commissioner v RTC ${ }^{93}$ also demonstrate the importance of the override provision in enabling the RTC to maximize profits. In Colorado State Banking Board, a bank reduced its bid from $\$ 675,000$ to $\$ 75,000$ for two thrifts when it became apparent that it would have to individually charter and capitalize the thrifts as separate banks. ${ }^{94}$ In Arkansas State Bank Commissioner, the RTC was able to capture a $\$ 1.5$ million pre-

${ }^{87} 12$ USC \& 1441a.

8s 12 USC $\S 1441 \mathrm{a}(\mathrm{b})(3)(\mathrm{C})(\mathrm{iv})$.

${ }^{89}$ No Civ-90-0532-SC, slip op at 1-2, 1990 US Dist LEXIS 18584 (D NM), aff'd, 926 F2d 931 (10th Cir 1991).

${ }^{\circ} \mathrm{Id}$.

9x Id. See also NM Stat Ann § 58-5-3 (1978) (permitting branch banking on a countywide basis).

${ }^{82} 926$ F2d 931 (10th Cir 1991).

${ }^{93} 911$ F2d 161 (8th Cir 1990).

94 926 F2d at 935-36. 
mium by selling all twenty branch offices of a failed thrift conditioned upon the RTC's override of state branch banking laws. ${ }^{95} \mathrm{Al}$ though there were other bids for the thrift, none of them offered to purchase all twenty of the branch offices. ${ }^{96}$ Moreover, many of the other bids also requested an override of state banking laws. ${ }^{97}$

The alternatives to being able to operate the acquired savings associations as bank branches are not attractive to acquiring banks. The current lack of public confidence in the savings and loan industry and other expenses associated with running a savings and loan make it unlikely that banks will want to acquire failed thrifts and continue to operate them as savings and loans. ${ }^{98}$

Likewise, it is not an appealing prospect for an acquiring bank individually to capitalize and charter each branch of an insolvent or failed savings association as a separate bank under applicable state laws-the $\$ 600,000$ price disparity between the two offers in Colorado $v$ RTC demonstrates this. Bank applications are lengthy and easily challenged by banking competitors. ${ }^{99}$ Consequently, it might take more than two years after the initial filing before a bank could operate the branches of a failed thrift as separate banks. ${ }^{100}$ Selling branches independently is also undesirable from the RTC's perspective; each branch office would need to be marketed individually. Given the difficulty the RTC has in selling complete thrifts, together with its branch offices even with its override authority, the likelihood of successfully marketing each branch office of a thrift separately is dim.

3. Section 1823(k)(4): branching provisions.

The branching provisions of $\S 1823(\mathrm{k})(4)$, the principal provision relied upon by states opposing the Override Regulation, do

ss 911 F2d at 163.

98 Id.

${ }^{92}$ Id.

98 For instance, the cost of deposit insurance is higher for savings and loan associations than it is for banks. Moreover, with the bad publicity surrounding the savings and loan industry due to the insolvency of the Federal Savings and Loan Insurance Corporation (FSLIC), the demand for savings and loan associations is virtually nonexistent. See Jonathan R. Macey and Geoffrey R. Miller, Federal Regulation of Banking 90 (forthcoming, 1992).

"9 For an example of burdensome litigation arising from a competitor's ability to object to a new bank charter, see First National Bank of Fayetteville $v$ Smith, 508 F2d 1371 (8th Cir 1974).

${ }^{100}$ Id at $1375-76$. 
not resolve the issue. As the appellate courts have demonstrated, ${ }^{101}$ the section is ambiguous. It provides:

If a merger, consolidation, transfer, or acquisition under this subsection involves a savings association ... and a bank ... a savings association may retain and operate any existing branch or branches or any other existing facilities. If the savings association continues to exist as a separate entity, it may establish and operate new branches to the same extent as any savings association that is not affiliated with a bank holding company. ... ${ }^{102}$

Read narrowly, this provision only authorizes the RTC to allow savings. associations that are acquired by banks but continue to operate as savings associations to retain and "operate new branches to the same extent as any savings association." If this interpretation is correct, however, the provision is silent on whether the branches of a failed thrift can be operated as branches of an acquiring bank. The question then becomes how to construe this legislative silence.

Since $\S 1823(k)(4)$ only gives explicit authority for savings associations to operate branches of failed thrifts, one inference is that this silence implicitly prohibits a similar license for 'banks. Such a reading presumes that only those activities specifically enumerated may preempt state laws.

This interpretation, however, would be inconsistent with $\S 1823(\mathrm{k})(1)$ 's broad grant of authority to the RTC to override state laws, and in particular, the text of $\S 1823(\mathrm{k})(1)(v i)$, which specifically lists what state restrictions cannot be overridden by the RTC. If Congress intended to allow the RTC to override state laws only for activities that were explicitly authorized by the text of the section, there would have been no need to limit the RTC's override power in $\S 1823(\mathrm{k})(1)$ (vi). The fact that these limits were expressly described implies that Congress expected the RTC to exercise its override power in situations not specifically authorized by the text. Thus $\S 1823(\mathrm{k})(4)$ 's silence on branch banking laws should not be read as a restraint on the RTC's override power. If Congress had sought to limit the RTC's ability to override banking laws, it would have included this limit within the section that ex-

101 Both sides in these cases have twisted this text in hopes of finding a congressional intent regarding the sanctity of branch banking laws. Arkansas State Bank Commissioner, 911 F2d at 174; Colorado State Banking Board, 926 F2d at 943.

10212 USC $\$ 1823(\mathrm{k})(4)(\mathrm{A})$. 
plicitly describes what state restrictions are beyond the RTC's domain. ${ }^{103}$

\section{B. Legislative History}

The legislative history of $\S 1823(\mathrm{k})(1)$ and $\S 1823(\mathrm{k})(4)$ confirms that the RTC's Override Regulation is consistent with the intent of Congress. At first glance, several remarks made on the floors of the House and the Senate appear to undercut the RTC's authority to override branch banking laws. However, a closer look reveals that these comments, to the extent that individual remarks on the floor of the House and Senate should carry weight in statutory interpretation at all, do not address the RTC's authority under the emergency acquisition provisions of $\S 1823(\mathrm{k})$.

\section{Section $1823(k)(1)$.}

The legislative history of $\S 1823(\mathrm{k})(1)$ derives from Senate Bill $774 .^{104}$ (The language of $\mathrm{S} 774$ is identical to the language of FIRREA § 1823(k).) The Senate Report to S 774 emphasizes the substantial authority Congress granted to the RTC to dispose of failed thrifts during emergency acquisitions:

[N] ew section 13(k) [\$ 1823(k) of FIRREA] can be used to override all state laws (including State constitutions) with one exception: section $13(\mathrm{k})$ does not override state laws that restrict the activities of a savings association on behalf of any other entity. The intent of the prohibition is illustrated by State insurance laws. Under section $13(\mathrm{k})$, State laws prohibiting a savings association from being affiliated with an insurance company may be overridden, but not State laws that prohibit a savings association from marketing insurance products on behalf of an insurance company. ${ }^{105}$

Given the language of the Senate Report, it is unlikely that Congress intended to permit an override of all state laws and constitutions, yet stopped short of permitting an override of branch banking restrictions.

The House Report parallels the Senate Report, explaining that $\S 1823(\mathrm{k})$ "permits an override of the laws of any state that

${ }^{103} 12$ USC $\S 1823(\mathrm{k})(1)(\mathrm{A})(\mathrm{vi})$.

${ }^{104} \mathrm{~S} 774,101$ st Cong, 1st Sess (1989), in S Rep No 101-19 (cited in note 47).

${ }^{105}$ See Section by Section Analysis of S 774, in 135 Cong Rec S6912 (cited in note 96). 
constitute a material impediment to supervisory acquisitions."108 As previously noted, state branch banking restrictions certainly materially impede acquisitions of failed thrifts by banks pursuant to $\S 1823(\mathrm{k})(1)$.

\section{Section $1823(\mathrm{k})(4)$.}

The legislative history of $\S 1823(\mathrm{k})(4)$, the principal provision relied upon by states arguing that the RTC cannot override state branch banking restrictions, likewise does not reveal a congressional intent to modify the RTC's broad authority to override state law. Moreover, the legislative history of this section does not specifically address branch banking laws. The House and Senate reports only discuss the activities of savings associations that continue to operate their branches as savings associations. ${ }^{107}$ Those reports never address the issue of branch banking restrictions.

\section{Remarks of Senator Riegle and Congressman Leach.}

States opposing the Override Regulation have also argued that two comments made during the House and Senate floor debates militate against allowing a preemption of state branch banking laws. ${ }^{108}$ The Senate dialogue progressed as follows:

Mr. WIRTH: I would like to . . clarify provisions in the legislation concerning the conversion of thrift charters to bank charters. Is it correct that the provisions of this act that permit thrifts to be converted to banks are not intended to allow banks ... [to] operate branches that do not comply with the laws... in the respective States where such banks are located?

Mr. RIEGLE: The Senator's statement is correct. ${ }^{109}$

Congressman Leach of the House Banking Committee repeated the same words in the House. ${ }^{110}$ These statements do suggest that

${ }^{106}$ HR Rep No 101-54 at 336 (cited in note 50).

${ }^{107} \mathrm{~S}$ Rep No 101-19 (cited in note 47); HR Conf Rep No 101-222, 101st Cong, 1st Sess 393 (1989).

108 Arkansas State Bank Commissioner, 911 F2d at 174; Colorado State Banking Board, 926 F2d at 940.

109135 Cong Rec S10,200 (Aug 4, 1989).

110 Congressman Leach stated:

$[P] r o v i s i o n s$ of this act that permit thrifts to be converted to thrifts [sic] are not intended to allow banks resulting from such conversions [to] operate branches that do not comply with laws relative to establishment and operation of bank branches . . . in the respective States where such banks are located. 
Congress did not intend to permit overrides of branch banking restrictions during routine mergers of thrifts with banks. However, the remarks simply do not refer to the emergency acquisition provisions of $\S 1823(\mathrm{k})$. Neither Senator Riegle nor Congressman Leach specifically addressed the RTC's expanded ability to override state laws during emergency acquisitions. Instead, they only referred to a conference report provision describing the RTC's general ability to merge savings associations with banks during ordinary circumstances. The emergency acquisition provisions of $\S 1823(\mathrm{k})$ were addressed later in the proceedings. Emergency acquisitions are clearly an exceptional category, a position reinforced by their isolation within the congressional report (they appear in a distinct section of the report under the caption, "FDIC's Assistance and Default Prevention Authority"). ${ }^{111}$ This position is also reinforced by the statutory language allowing state laws and even state constitutions to be preempted during such emergencies. ${ }^{112}$ Because the provisions of $\S 1823(\mathrm{k})(1)$ apply only to potentially cataclysmic circumstances, ${ }^{113}$ it is unlikely that remarks on general charter conversions would be thought to encompass this limited situation. This interpretation is bolstered by the Senate Report that expressed only one exception to the RTC's ability to override state law.

Moreover, the fact that these statements were uttered by two legislators during floor debates does not conclusively demonstrate that they represent the collective intent of Congress. ${ }^{114}$ In fact, the Supreme Court shuns reliance on the passing comments of members of Congress when inquiring into legislative intent. Rather, the Court relies more heavily upon committee reports which "represent the considered and collective understanding of those Congressmen involved in drafting and studying proposed legislation." 115 Thus, if Congress intended branch banking laws to be an

135 Cong Rec H4980 (Aug 3, 1989).

${ }^{111}$ HR Conf Rep No 101-222 at 398 (cited in note 107).

112 See text accompanying notes 104-05.

113 The emergency acquisition provisions apply only when "severe financial conditions threaten the stability of a significant number of savings associations, or of savings associations possessing significant financial resources." 12 USC \$ $1823(\mathrm{k})(1)$.

11، See Geoffrey P. Miller, Interstate Banking in the Court, 1986 S Ct Rev 179, 193 (1986) ("II]t is disingenuous to rely, in statutory interpretation, on the remarks of a single legislator in floor debate, even when that legislator happens to have sponsored the measure in question. The intent of Congress should account for all those whose votes were necessary to passage.").

${ }_{115}$ Zuber v Allen, 396 US 168, 186 (1969). See also Weinberger v Rossi, 456 US 25, 35 (1982); United States v O'Brien, 391 US 367, 385 (1968). 
exception to the RTC's ability to override state laws, it could have included this intention in either the committee reports or the statutory language. It did not.

\section{The McFadden Act and the Canon Against Implied Repeals}

Some states, appealing to the principle that a general statute should not be read to nullify a specific statute absent Congress's explicit intent to do so, ${ }^{116}$ have argued that the RTC's interpretation of $\S 1823(\mathrm{k})$ is impermissible since it would constitute an implicit repeal of the McFadden Act. ${ }^{117}$ This argument, however, is erroneous.

To apply the canon, a court should find that the statute being construed is a general one, and that it does not precisely speak to the issue at hand. Neither of these conditions is met here. FIRREA is not a general statute, but a specific statute directed at resolving the savings and loan crisis. In addition, FIRREA explicitly gives the RTC the power to override state laws during emergency acquisitions.

Moreover, the Override Regulation does not repeal the McFadden Act (implicitly or otherwise), for it does not authorize full unlimited branch banking for all banks. Rather, branch banking laws are only overridden in limited circumstances-when banks purchase thrifts and the thrifts' existing branch offices in an emergency acquisition. Second, FIRREA is also only a temporary measure for resolving the savings and loan crisis. Once the crisis is resolved and the RTC terminates in 1994, the McFadden Act will remain in full force. Rather than violating the canon against implied repeals, this interpretation is consistent with the equal imperative to give effect to apparently conflicting statutes as long as this can be done without distorting the sense and purpose of either of the acts. ${ }^{118}$

Finally, even if the RTC's Override Regulation constitutes an impermissible repeal of the McFadden Act, the RTC could still authorize state banks to operate the branches of failed thrifts in contravention of state law, since the McFadden Act governs the

116 The Supreme Court has held that "where there is no clear intention otherwise, a specific statute will not be controlled or nullified by a general statute." Radzanower $v$ Touche Ross \& Co., 426 US 148, 153 (1976). See also Crawford Fitting Co. v J.T. Gibbons, Inc., 482 US 437,445 (1987) (Marshall dissenting). This principle is commonly referred to as the canon against implied repeals.

11 See footnote 34 and accompanying text.

118 See, for example, Watt v Alaska, 451 US 259, 267 (1981). 
branching activities of national banks but not the branching activities of state banks. The intent of the McFadden Act however was to equalize the branching treatment of state and national banks. ${ }^{119}$ The states' interpretation of the Override Regulation would undermine the McFadden Act's goal of implementing competitive equality between national banks and state banks. ${ }^{120}$ The Override Regulation as it stands now preserves the level of competitive equality envisioned by the McFadden Act.

\section{Chevron And Policy Considerations}

Even if the plain text and legislative history are not dispositive, the RTC's Override Regulation should still be upheld under the Chevron standard of review. Further, important policy considerations favor overriding branch banking laws. This section will analyze the Override Regulation in light of the Chevron standard and investigate the policy implications of an override of branch banking restrictions.

\section{A. The Chevron Standard}

In the landmark case of Chevron U.S.A. Inc. $v$ Natural Resources Defense Council, Inc., ${ }^{121}$ the Supreme Court announced the standard for reviewing an agency's interpretation of a statute it is charged with enforcing. If a statute is "silent or ambiguous with respect to a specific issue," the agency's interpretation need only be a "permissible" construction of the statute. ${ }^{122}$ Accordingly, a court's duty is not to choose the best interpretation, but rather to ensure that the interpretation reached by the agency is "reasonable" and not "arbitrary, capricious, or manifestly contrary to the statute."123

The rationale for such a deferential standard of review rests on the recognition that in order to administer a congressionally-

110 See text accompanying notes 31-38.

120 Based on the McFadden Act, the Supreme Court adopted the doctrine of competitive equality. This doctrine confines the permissible activities of national banks to the permissible activities of state banks. The doctrine responds to the concern that favoritism for one banking system could put the other system at a competitive disadvantage. See Henry N. Butler, The Competitive Equality Doctrine and the Demise of Intrastate Bank Branching Restrictions, 55 Tenn L Rev 703, 705-06 (1988).

121467 US 837 (1984). For a critique of the Chevron standard of deference to administrative agencies, see Cass R. Sunstein, Interpreting Statutes in the Regulatory State, 103 Harv L Rev 405, 444-46 (1989).

122 Chevron, 467 US at 843.

123 Id at $843 \mathrm{n} 11,844$. 
enacted program, an administrative agency must formulate policy and make rules to fill any implicit or explicit gaps left by Congress. ${ }^{124}$ If Congress implicitly leaves a gap for an agency to fill and the agency's interpretation is reasonable, the courts may not overturn the agency's interpretation. ${ }^{125}$ If the agency must reconcile conflicting policies, the courts will review only whether the agency's interpretation is a reasonable accommodation among the various policies. ${ }^{126}$

Applying Chevron to the Override Regulation, the RTC's interpretation of $\S 1823(\mathrm{k})$ is valid. Even if the plain text of that section did not favor the RTC's Override Regulation, it could hardly be claimed that the statute unequivocally supports the states' position. At best, there are plausible arguments for each interpretation. However, the fact that plausible arguments can be presented to support different interpretations of $\S 1823(\mathrm{k})$ raises the specter of ambiguity. ${ }^{127}$ An agency's interpretation of an ambiguous statute triggers the Cheuron standard of review. The RTC's interpretation of the Override Regulation is not "arbitrary, capricious, or manifestly contrary to the statute."128 As discussed above, the language and legislative history of $\S 1823(\mathrm{k})$ support the RTC's conclusion that preemption of state branch banking restrictions is authorized. Therefore, the RTC's interpretation should satisfy the liberal Cheuron standard.

\section{B. Policy Concerns}

This Comment's conclusion is not only supported by the language and legislative history of FIRREA, and not only allowable under Chevron, but also has favorable policy ramifications. These policy considerations entail weighing the states' interest in maintaining branch banking laws against the interest in resolving failed thrifts. The latter easily outweighs the former: branch banking restrictions are largely misguided and obsolete, and the resolution of failed thrifts is of paramount national importance.

124 Id at 843.

123 Id at 844 .

${ }^{128}$ Id at 845.

${ }^{127}$ See Ronald Dworkin, Law's Empire 352 (Harvard, 1986) ("We will not call a statute unclear unless we think there are decent arguments for each of two competing interpretations of it"). The ambiguity is underscored by the fact that nine judges have reviewed the statutory language and come to differing conclusions. See note 13.

${ }^{128}$ Chevron, 467 US at 843. 
1. Misguided rationales for branch banking restrictions.

Branch banking restrictions do not further the three major rationales usually cited in their favor: concern for the needs of the local community, worries about the soundness of banks, and fears of collusion. In reality, branch banking restrictions detract from the soundness of banking institutions, heighten the potential for collusion, and only serve the needs of the local community at the expense of their investors.

a) Service to local communities. Critics of branch banking argue that branch banking restrictions better serve the needs of the local community. They contend that branch banks siphon the credit out of communities and loan the money elsewhere. ${ }^{129}$ Thus, branch banking restrictions ensure that local banks control credit in the communities they serve, thereby providing a steady supply of funds for the local community.

This contention is without merit. A market economy directs resources to sectors of the economy that make the most efficient use of them. ${ }^{130}$ Thus if branch banks channel funds away from the community where they are deposited, this is because more efficient uses of the funds may be found elsewhere. ${ }^{131}$ Moreover, because bankers have a fiduciary responsibility to seek the best investment opportunities for customer deposits, even local bankers should invest their customer deposits abroad if more attractive opportunities exist there. Thus, the local needs argument may actually be a "thinly veiled argument that banks should act contrary" to their self interest and to the public at large in order to provide a special favor for one set of customers."132

b) Safety and soundness of banking institutions. Critics of branch banking also fear that the risk of widespread bank failures will increase significantly if branch banking is allowed. ${ }^{133}$ Branch banking throughout the state makes financial communities more interdependent. If branch banking is restricted, these advocates argue that bank failures will be confined to local communities. Thus, branch banking restrictions promote safety and soundness in the banking industry. views).

129 See Miller, 1986 S Ct Rev at 209 (cited in note 114) (noting, but not endorsing, these

130 Id at 209-10.

131 Id at 210.

132 Id.

${ }^{133}$ See id at 211 (noting, but not endorsing, this view). 
This argument, however, is not well founded. The large number of unit bank failures during the Great Depression led many to believe that branching actually provides greater stability to the industry, by insulating banks from the fate of local industries. ${ }^{134}$ As Henry Butler stated in his work on intrastate branch banking: "[T] he ability to diversify their deposit base allows banks and bank holding companies to reduce their overall risks associated with economic fluctuations in local markets."135 Instead of making banks vulnerable, the Override Regulation will actually help strengthen the banking industry in the states that still cling to branch banking restrictions.

c) Collusion and economic inefficiency. Some argue that branch banking leads to collusion, monopolistic pricing, and economic inefficiency. ${ }^{136}$ In reality, the opposite is true; these unfavorable conditions are actually the effect of branch banking restrictions. Branch banking restrictions protect local banks from outside competition, giving these banks a virtual monopoly on the banking industry in their area. This domination certainly does not lead to the level of economic efficiency that normally results from competition. ${ }^{137}$

2. Obsolescence of branch banking restrictions.

In addition to being counterproductive, state restrictions on branch banking are fast becoming obsolete.

${ }^{134}$ Comment, $72 \mathrm{Ky} \mathrm{L} \mathrm{J} \mathrm{at} 713$ (cited in note 23). See also Staff of Senate Subcommittee on Financial Institutions of the Senate Committee on Banking, Housing and Urban Affairs, 94th Cong, 2d Sess, Compendium of Issues Relating to Branching by Financial Institutions 27 (Oct 1976) (describing Comptroller Pole's criticism of unit banking because of the vast number of small bank failures during the Great Depression).

${ }^{135}$ Butler, 55 Tenn $L$ Rev at 268-29 (cited in note 120). For a critique of the assertion that a greater ability to diversify leads to greater safety, see Miller, $5 \mathrm{~S} \mathrm{Ct}$ Rev at 213 (cited in note 114). view).

${ }^{138}$ See Miller, $5 \mathrm{~S}$ Ct Rev at 217 (cited in note 114) (noting, but not endorsing, this

${ }^{137}$ In his 1981 Report to Congress, President Carter indicated the anti-competitive consequence of branch banking restrictions:

To the extent that restraints on branch banking succeed in impeding the expansion of retail deposit taking and related activities, those restraints are anti-competitive ... McFadden Act restraints [on branch banking] also impose inequities on banks vis-a-vis their nonbank competitors and on the average customer vis-a-vis wealthy individuals and major corporations, for whom geographic convenience is frequently a relatively unimportant factor in establishing banking relationships.

Quoted in Shapiro, $499 \mathrm{PLI} /$ Corp 291 (cited in note 46). 
a) Competition from savings and loan associations. Branch banking limitations have already been eroded by the participation of savings and loan associations in the "banking" business. Historically, savings and loan associations did not compete with banks because their investment activities were limited primarily to home mortgages. ${ }^{138}$ The Garn-St.Germain Act ${ }^{139}$ reduced this competitive disadvantage by expanding the lending and investment powers of federally-chartered savings associations. ${ }^{\mathbf{1 4 0}}$ Many states have similarly broadened the investment powers of state-chartered savings associations. ${ }^{141}$

The blurring of the distinction between banks and savings associations has led courts to employ a functional approach to defining "banks" under the McFadden Act. Because savings associations are now engaged in the "banking business," they are considered "state banks" for purposes of the McFadden Act. ${ }^{142}$ Consequently, courts have held that national banks may branch to the same extent as any state savings association engaged in the "banking business." 143 Since savings and loan branching laws are usually more liberal, the policy paradoxically gives national banks a wider authority to branch than it gives to state-chartered banks. Thus, instead of endangering local banks, the RTC's Override Regulation will actually help state banks compete by giving them a unique ability to purchase thrifts and obtain their branching networks.

b) Technological advances. Technological advances have also made branch banking restrictions outdated. With telecommunications advances and the advent of electronic funds transfer, it has become increasingly difficult to determine what constitutes a branch of a bank. Currently, the concept of a branch has been stretched far enough to prevent the operation of cash machines outside certain geographic boundaries. Such a policy deprives consumers of a substantial convenience. The branch banking laws-enacted in an age of limited travel-are hardly appropriate for today's culture of mobility.

\footnotetext{
${ }^{138}$ Clark, Murtagh, and Corcoran, 45 Bus Law at 1016 (cited in note 6).

13912 USC $\S \S 36$ et seq (1991).

140 Id.

111 Id.

${ }^{142}$ See Department of Banking and Consumer Finance v Clarke, 809 F2d 266, 270-71

${ }^{143}$ Volunteer State Bank, 684 F Supp at 966; Independent Bankers Association, 917
} (1987). F2d at 1129; State of Texas v Clarke, 690 F Supp 573, 576 (1988). 
3. Significance of resolving failed thrifts.

Weighed against the misguided and obsolescent state branching restrictions is the nation's interest in resolving failed thrifts. It would be hard to underestimate the importance of this interest. The extraordinary cost to U.S. taxpayers of bailing out the savings and loan industry, the Override Regulation's potential to make failed thrifts marketable, and the limited effect that the Override Regulation will have on state branching restrictions all weigh heavily in favor of allowing the override.

a) Cost to taxpayers. FIRREA is the largest governmental bailout in U.S. history. It could cost U.S. taxpayers $\$ 157$ billion over the next thirty-three years to resolve the crisis. ${ }^{144}$ This financial burden will be borne by all U.S. taxpayers regardless of geographic locations. Since more than half the states do not restrict branch banking, ${ }^{145}$ the override regulation would only preempt state law in a minority of states. Because taxpayers nationwide are paying for the resolution of federally insured thrifts, individual state interests are justifiably preempted by the national interests of U.S. taxpayers.

b) RTC's duty to maximize profit. Given the enormous cost of the S\&L crisis, the RTC needs wide discretion in order to be able to maximize the costs from the sales of thrifts. In some situations, failed thrifts have absolutely no market value. Under these circumstances, freedom from branch banking restrictions represents the only premium that the failed thrift offers. Since the RTC is required to maximize the value from the sale of failed thrifts, it should take every reasonable measure to increase those thrifts' market value. If an override of branch banking laws is the only way to maximize the value of the thrifts, then the RTC should have the ability to do so. The alternative to maximizing the value of thrifts in this way would be to protect state branch banking laws by transferring the lost value to the shoulders of the U.S. taxpayers.

c) Limited effect of the Override Regulation. Furthermore, the Override Regulation will only affect branch banking laws in limited circumstances. FIRREA only authorizes an override of state laws when the RTC feels that financial conditions threaten a 
significant number of savings associations. ${ }^{146}$ Even then, branch banking will still be limited to situations where banks purchase thrifts with preexisting branch networks. Finally, the Override Regulation is only a temporary remedy; both the RTC and the Override Regulation will terminate on August 9, 1994. ${ }^{147}$

\section{CONCLUSION}

The RTC's Override Regulation is consistent with the plain meaning, legislative history, and policy concerns behind FIRREA. Even assuming that an ambiguity exists concerning the scope of the authority granted to the RTC, administrative agencies are granted wide deference in interpreting their enabling statutes. Since the RTC's interpretation is reasonable rather than capricious or arbitrary, the Override Regulation should be upheld.

The RTC's Override Regulation is also an essential aspect of its regulatory power. The regulation allows the agency to fulfill its statutorily-mandated duty to maximize the profit and minimize the loss realized from the sale of failed thrifts. The Override Regulation also helps reduce the financial burden on the U.S. government and taxpayers. Although the Override Regulation will have an effect on local financial markets, this effect will be limited and temporary. Given the severity of the savings and loan crisis, it is well justified.

116 55 Fed Reg 22323. Also see 12 USC § 1823(k)(1).

147 USC \& 1441a(o). 
- 